\title{
Role of the facial artery musculomucosal flap in the reconstruction of palatal defects.
}

\author{
Hawree Abdulsattar Hasan ${ }^{1}$, Ari Raheem Qader ${ }^{2}$, Ala Esmail Shakur ${ }^{1}$, \\ Ari Hasan Rashid ${ }^{1}$ and Shakhawan Saeb Zorab ${ }^{1}$ \\ ${ }^{1}$ Sulaimaniya Burn and Plastic Surgery Hospital, Sulaimaniyah, Kurdistan Region. Iraq. \\ ${ }^{2}$ Collage of Medicine, University of Slemani, Sulaimaniyah, Kurdistan Region. Iraq.
}

Key words: cleft palate; FAMM flap; inferiorly based; oral cavity; palatal fistula; superiorly based.

\begin{abstract}
The facial artery musculomucosal flap (FAMM flap) is a convenient option for covering complicated palatal defects, as it is a local flap inside the oral eavity with good tissue quality and minimal drawbacks. The present prospective study included 17 patients, 7 males and 10 females. Most of the patients had palatal fistulae, after cleft palate surgical repair; only one had a post-traumatic palatal defect. Superiorly based FAMM flaps were used for eight patients, and inferiorly based FAMM flaps were used for nine patients. A speech specialist assessed all patients, postoperatively. The range of follow-up time was from two to four years. In the majority of cases, reconstruction was successful and uneventful. Patients were satisfied regarding oral function. Complications were minor, which include incomplete coverage, bulkiness, temporary hardness and dimpling. The FAMM flap is a very useful, versatile, and technically easy flap for covering difficult palatal defects.
\end{abstract}




\title{
Papel del colgajo músculo-mucoso de la arteria facial en la reconstrucción de defectos palatinos.
}

\author{
Invest Clin 2021; 62 (4): 307-315
}

\begin{abstract}
Palabras elave: fisura de paladar; colgajo FAMM; base inferior (flujo anterógrado); cavidad oral; fistula de paladar; base superior (flujo retrógrado).
\end{abstract}

\begin{abstract}
Resumen. El colgajo músculo-mucoso de la arteria facial (FAMM) es una opción conveniente para cubrir los defectos palatinos complicados, como un colgajo local dentro de la cavidad oral, con buena calidad de tejido y mínimos inconvenientes. Diecisiete pacientes, 7 masculinos y 10 femeninos, fueron incluidos en nuestro estudio prospectivo. La mayoría de los pacientes tenían una fístula de paladar después de la reparación quirúrgica de fisura de paladar; solo uno tenía un defecto palatino postraumático. Se utilizaron los colgajos FAMM de base superior en 8 pacientes, y los colgajos FAMM de base inferior se utilizaron en 9 pacientes. Todos los pacientes fueron evaluados en el postoperatorio por un especialista en habla. El intervalo de tiempo de seguimiento fue de 2 a 4 años. En la mayoría de los casos, la reconstrucción fue exitosa y sin incidentes. Los pacientes quedaron satisfechos con respecto a la función oral. Las complicaciones fueron menores, e incluyeron cobertura incompleta, aumento de volumen, dureza temporal y hoyuelos. El colgajo FAMM es un colgajo muy útil, versátil y técnicamente fácil para cubrir los defectos palatinos difíciles.
\end{abstract}

Received: 04-04-2021 Accepted: 31-05-2021

\section{INTRODUCTION}

The FAMM flap is an axial flap composed of mucosa and submucosa from the intraoral cheek, part of the buccinator muscle and the deepest part of the labial orbicular muscles including the facial artery $(1,2)$. Pribaz et al. discussed the FAMM flaps, which consist of the mucosa, submucosa, a small amount of buccinators muscle, the deeper plane of the orbicularis oris muscle and the facial artery and venous plexus (3).

The buccinator muscle is a wide, flat, quadrangular muscle; its medial surface is covered by submucosa and mucosa. Its considered part of the sphincteric muscle complex used for sucking, whistling, propelling food, and voiding the oral cavity. This muscle's blood supply is from the buccal artery and small branches from the alveolar artery (4). The facial artery, a branch of the external carotid artery, hooks around the mandible body immediately anterior to the masseter muscle. It courses deep into the risorius, zygomaticus major, and superficial lamina of the orbicularis oris muscle. It lies superficial to buccinators, the levator anguli oris, and the deep lamina of the orbicularis muscle. The facial artery is located approximately $1.5 \mathrm{~cm}$ (range 9.2 to $19.8 \mathrm{~mm}$ ) lateral to the oral commissure, giving rise to the superior and inferior labial arteries (5).

The FAMM flap can be designed according to its need as either superiorly based 
(antegrade) or inferiorly based (retrograde) flap, and both types have been proved to be reliable $(1,6)$. The superiorly based FAMM flap can be used to cover the defects in the hard palate, alveolus, nasal lining, upper lip and sometimes even the orbit. The inferiorly based FAMM flap can be used for defects in the alveolus, floor of the mouth, lower lip and vermillion and tonsillar fossa (7). FAMM flap can also be used in case of post-ablation maxillofacial defects, an inferiorly based FAMM flap can be used only for the facial artery. If possible, the linguofacial vein has been preserved in neck dissections. If the vein has been ligated, venous drainage can still be ensured by preserving wide soft tissue at the base (8).

Advantages over other regional flaps include its axial blood supply permitting the extended length, minimal donor-site morbidity, and flexibility to have either a superior or inferior pedicle. Drawbacks of FAMM include its difficulty of tunneling for palatal reconstruction in patients with intact dentition. These kinds of patients have to use a bite block to avoid chewing on the pedicle, and another operation is required for flap division (9). Other complications, like any other flaps, are partial or complete necrosis of the flap, buccal branch of facial nerve injury that might lead to oral corner asymmetry, particularly during difficult dissection (1). To minimize complications, careful dissection should be done so that the facial artery goes along the flap's whole length. The flap remains axial; also, care should be taken to prevent twists or constraints on the pedicle. With careful attention to these details, the FAMM flap remains reliable, versatile, and extremely useful (3).

The palatal defect can result mainly after excision of the tumor, cleft palate, oronasal fistulas, and alveolar, the floor of the mouth, and vermilion loss. Nasolabial flaps have been performed to reconstruct midfacial defects, and buccal flaps have been used to reconstruct midfacial defects $(10,11)$. Pribaz et al. (3) have designed by combining the principles of nasolabial and buccal mucosal flaps, FAMM flap.

This study's objective was to review functional results and complications that occurred in our cases with palatal defects that the FAMM flap have been used for them as a primarily or previously operated on cases.

\section{MATERIALS AND METHODS}

This prospective study included 17 cases with a palatal defect that attended the Sulaimaniya Burn and Plastic Surgery Hospital, Sulaimaniya city, Iraq. The patient's age was between 2 to 40 years, 7 of them were female, and 10 patients were male. Nine flaps were based inferiorly, and eight flaps were based superiorly. The most common cause of the palatal defect was palatal fistula after cleft palate surgical repair (15 cases); other causes of the palatal defect were primary wide palatal defect (one case), and bullet injury (one case) (Table I). Sixteen cases were secondary cases previously treated with other conventional modalities that failed, like turndown flap, tongue flap, buccal flap, and one of them has been previously, unsuccessfully treated with a FAMM flap.

A list of patient characteristics, indications and type of procedure is shown in Table I.

The FAMM flap can be designed superiorly or inferiorly based. All patients were under general anesthesia with endotracheal intubation. A mouth gag was inserted. Marking was outlined first outside using handheld Doppler ultrasound; the flap centered over the facial artery and one cm away from the month's angle, as shown in Fig. 1.

With the help of a small gauge needle, we determined the flap's edges from inside and marking it after marking the Stenson's duct. Then we did double-checking from inside through using a handheld Doppler ultrasound, as shown in Fig. 2.

The flap's orientation became oblique, and the width of the flap is ranged between 1.5 to $2 \mathrm{~cm}$ and was well anterior to the Stenson's duct. This is illustrated in Fig. 3.

Vol. 62(4): 307 - 315, 2021 
TABLE I

PATIENT CHARACTERISTICS \& TYPE OF PROCEDURE

\begin{tabular}{|c|c|c|c|}
\hline No. & Age \& Sex & History \& Diagnosis & Type of FAMM flap \\
\hline 1 & $12 \mathrm{y}, \widehat{\jmath}$ & Anterior palatal defect due to fistula. & Inferiorly based FAMM flap. \\
\hline 2 & $8 \mathrm{y}, \widehat{\jmath}$ & Anterior palatal defect due to fistula. & Inferiorly based FAMM flap. \\
\hline 3 & $9 y, \widehat{\jmath}$ & Anterior palatal defect due to fistula. & Superiorly based FAMM flap. \\
\hline 4 & $9 \mathrm{y}, \widehat{\jmath}$ & Anterior palatal defect due to fistula. & Superiorly based FAMM flap. \\
\hline 5 & $10 \mathrm{y}$, q & Anterior palatal defect due to fistula. & Inferiorly based FAMM flap. \\
\hline 6 & $8 \mathrm{y}$, 우 & Anterior \&mid palatal defect due to fistula. & Inferiorly based FAMM flap \\
\hline 7 & $8 \mathrm{y}$, ㅇ & Anterior \&mid palatal defect due to fistula. & Inferiorly based FAMM flap. \\
\hline 8 & $8 \mathrm{y},{ }_{0}^{\lambda}$ & Anterior \&mid palatal defect due to fistula. & Superiorly based FAMM flap. \\
\hline 9 & $2 \mathrm{y},{ }^{\lambda}$ & $\begin{array}{l}\text { Anterior \&mid palatal defect due to fistula, } \\
\text { with the history of buceal flap failure. } \\
\text { Right side. }\end{array}$ & Inferiorly based FAMM flap. \\
\hline 10 & $4 y, \hat{\jmath}$ & Anterior palatal defect due to fistula. & Superiorly based FAMM flap. \\
\hline 11 & $18 \mathrm{y}$, 우 & Mid palatal defect due to fistula. & Inferiorly based FAMM flap. \\
\hline 12 & $16 \mathrm{y}$, 우 & Unrepaired wide bilateral cleft palate. & $\begin{array}{l}\text { Inferiorly based FAMM flap used } \\
\text { for aiding cleft palate repair. }\end{array}$ \\
\hline 13 & $18 \mathrm{y}, \widehat{\jmath}$ & Bilateral alveolar cleft. & $\begin{array}{l}\text { Superiorly based FAMM flap \& } \\
\text { cancellous bone graft. }\end{array}$ \\
\hline 14 & $40 \mathrm{y}, \mathrm{o}^{\top}$ & Bullet injury causing big palatal fistula. & $\begin{array}{l}\text { Superiorly based FAMM flap \& } \\
\text { cancellous bone graft. }\end{array}$ \\
\hline 15 & $35 \mathrm{y}, \hat{\sigma}^{\lambda}$ & $\begin{array}{l}\text { Oronasal fistula, with a history of tongue } \\
\text { flap failure. }\end{array}$ & Superiorly based FAMM flap. \\
\hline 16 & $16 \mathrm{y}$, 우 & Anterior palatal defect due to fistula. & $\begin{array}{l}\text { Inferiorly based FAMM flap, } \\
\text { failed due to necrosis. }\end{array}$ \\
\hline 17 & $4 \mathrm{y}$, ㅇ & $\begin{array}{l}\text { Anterior \&mid palatal defect due to fistula, } \\
\text { which we did for her previously right } \\
\text { inferiorly based flap, and it failed }\end{array}$ & $\begin{array}{l}\text { Left Superiorly based FAMM } \\
\text { flap. }\end{array}$ \\
\hline
\end{tabular}

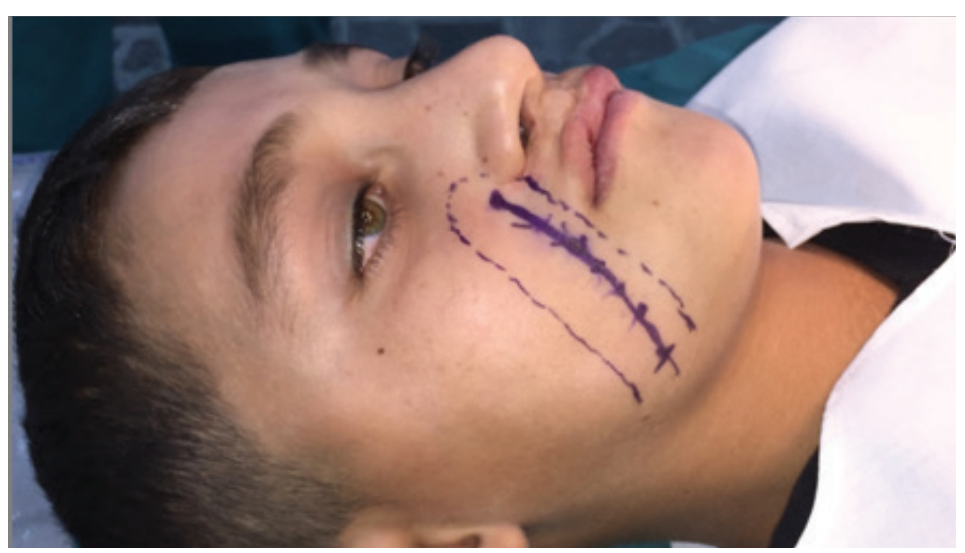

Fig. 1. Marking of the FAMM flap from outside. 


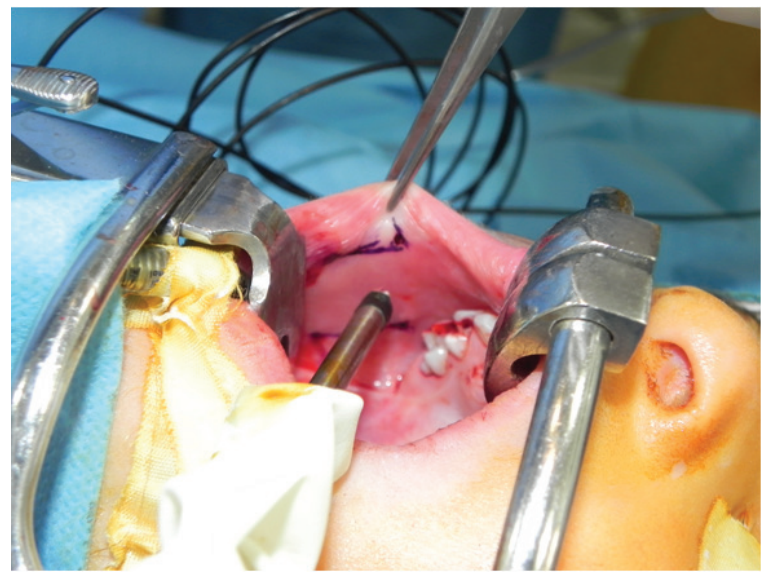

Fig. 2. Double-checking with the aid of a handheld Doppler.

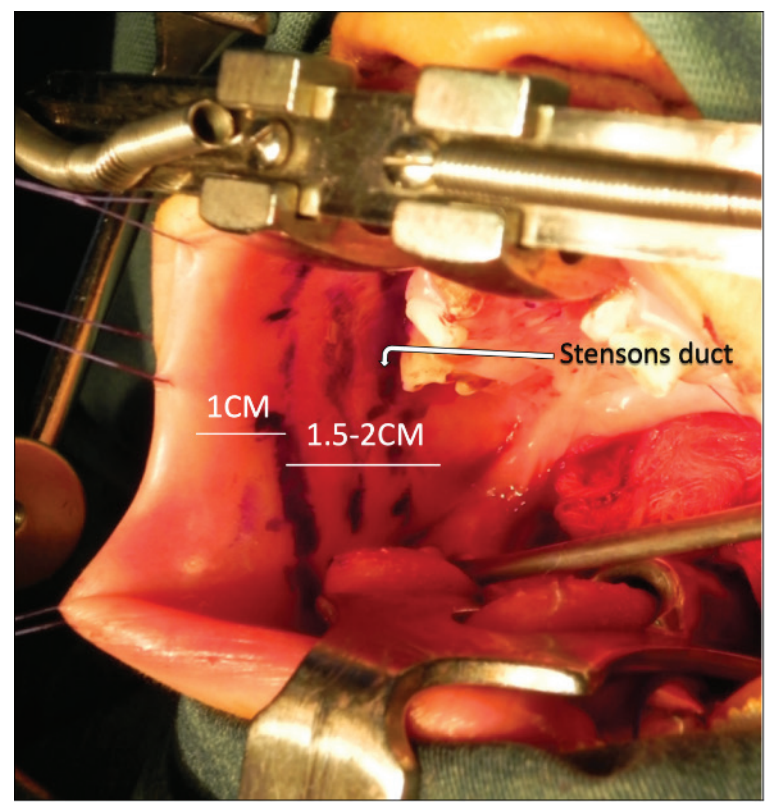

Fig. 3. Marking of the flap from inside.

After infiltration of lidocaine with adrenaline and waiting for 7 minutes, we did an incision using Colorado-tipped electrocautery through mucosa, then submucosa.

After incision of the buccinators muscle we searched for the facial artery as it is demonstrated in Fig. 4.

The dissection is carried out from distal to proximal according to the base of the flap, which is either superior or inferior as shown in Fig. 5.

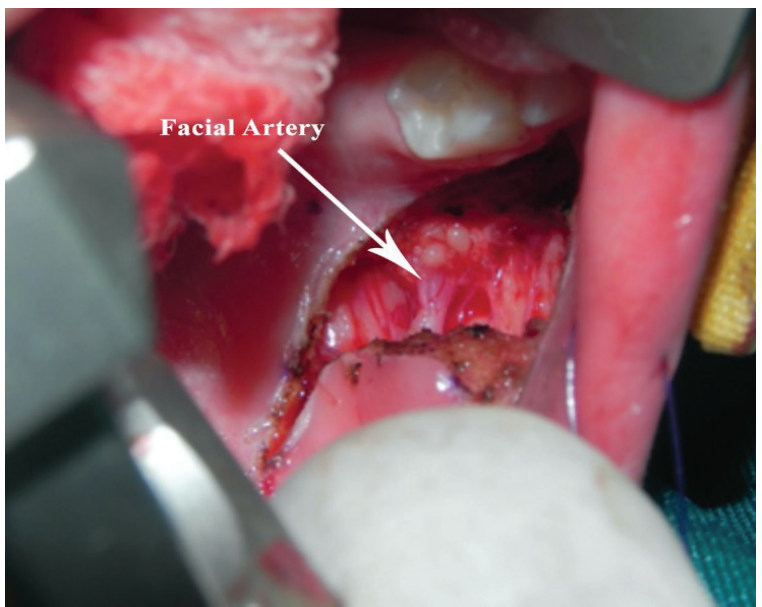

Fig 4. Dissection of the flap.

After identifying the facial artery, ligation and cutting of the artery was done, the rest of the flap was incised, and dissection was done just deep to the facial vessels with taking a small amount of the buccinators muscle and deep plane of the orbicularis oris muscle.

The facial artery was included along the whole axis of the flap, which is critical for making the flap axial and well perfused, and the length of the flap was between 8 to 13 em with length to width ratio $5: 1$, as stated in Fig. 6.

Then we did two layers of closure, which was possible in all 17 cases, by approximating the buccinators flap. We put a bite block in some cases of the superiorly based flap.

\section{RESULTS}

All cases were subjectively assessed in the postoperative period to determine the anatomical separation of the nasal eavity from the oral cavity and improve the patient's speech by a speech therapist. The results showed a good satisfactory improvement which was noticed in all of our cases. In the majority of cases, reconstruction was successful and uneventful. The flap's bulkiness was also noticed especially in the early weeks after surgery, without causing any problem during speech and eating. This problem was 

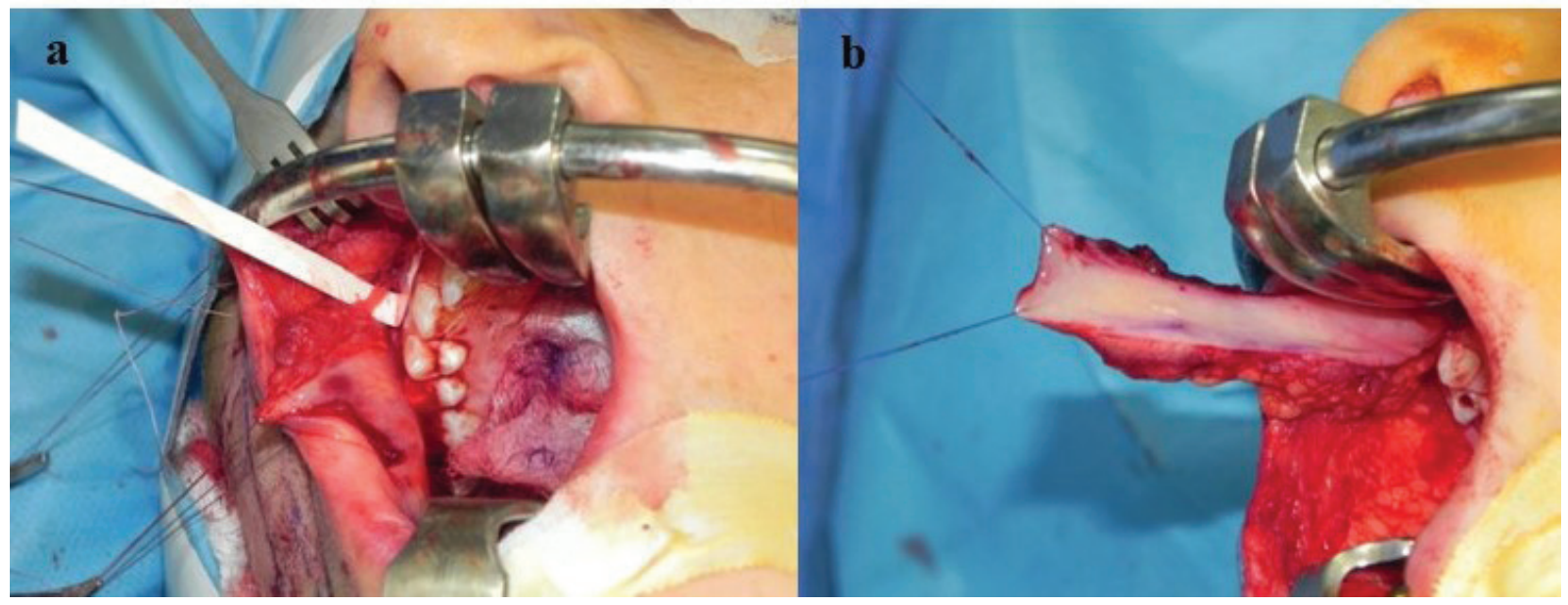

Fig. 5. a) Superiorly and b) inferiorly based FAMM flap
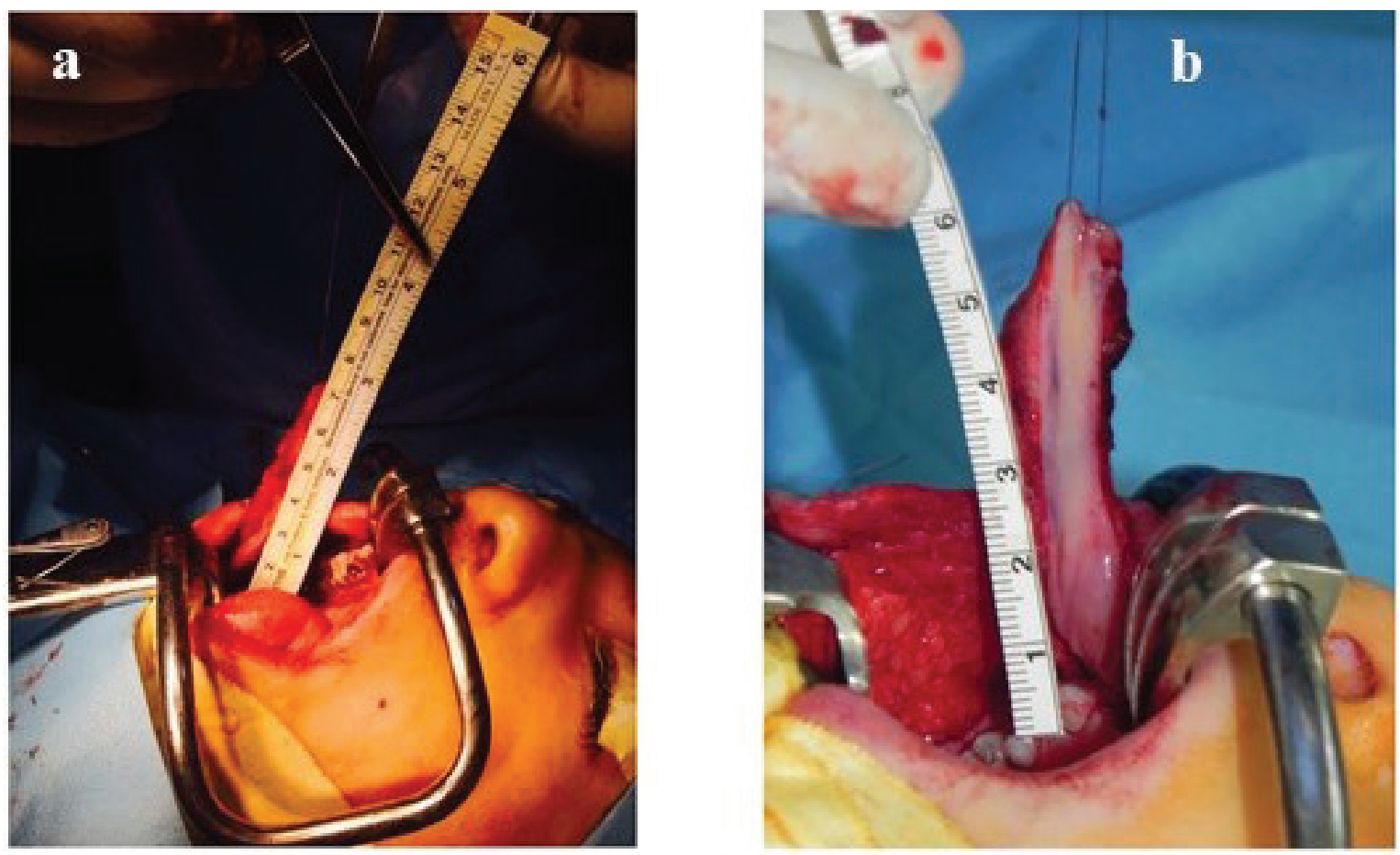

Fig.6. a) length and b) width of the flap.

gradually decreased in size with time. In one case, we were not able to close the defect completely by just using the FAMM flap due to the size of the defect, so there was a good improvement in the patient's speech with the help of speech therapy but still, the patient have fistula and nasal regurgitation.

\section{Flap viability}

In one of our cases (5\%), a 4-year-old female with a mid and anterior palatal defect, due to fistula post cleft palatal repair; a right side inferiorly based flap was used, the flap developed complete necrosis. The reason behind this was not explained, we did 
debridement and redo the surgery with the use of contralateral superiorly based FAMM flap with the good flap survival and viability. Another case (5\%) developed partial necrosis of the flap, we also did debridement of the necrotic tissue but fortunately, it did not affect the coverage of the defect and the overall result of the surgery.

\section{Donor side}

In all of our cases, primary closure was possible at the donor side. In the beginning, there were some kinds of tightness, especially during mouth opening, but this effect became better after time.

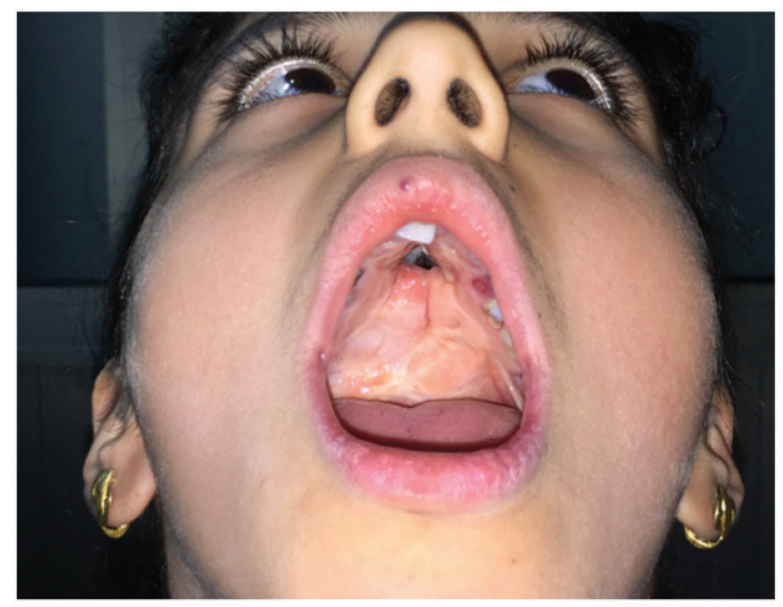

One case developed dimpling in the lower part of his check at the donor side. No muscle weakness during facial animation has been observed in all 17 cases as the facial nerve branches were preserved. Figs. 7- 9 are demonstrated in some of our cases.

\section{Patient satisfaction}

Patients were satisfied regarding oral function. Complications were minor, which include incomplete coverage, bulkiness, hardness at the donor site, dimpling, facial asymmetry and partial necrosis.

Fig. 7. 10 years old female. (inferiorly based FAMM flap done to close an anterior palatal fistula).

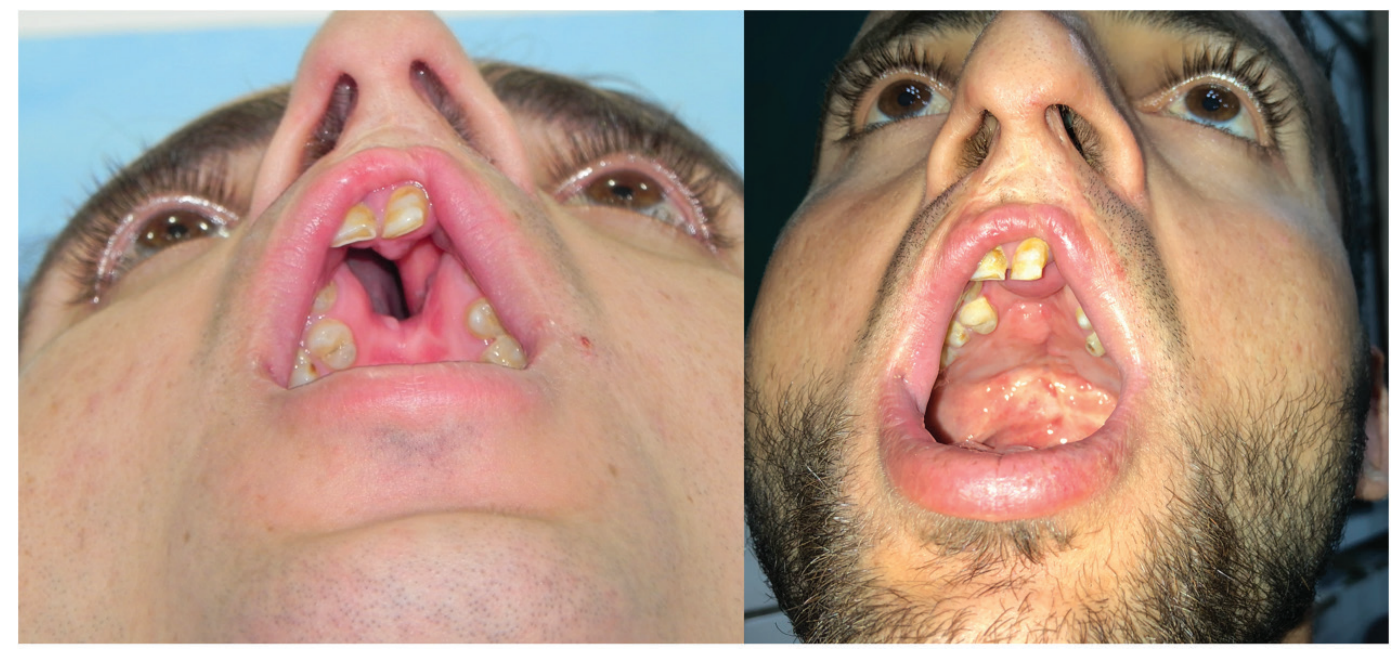

Fig. 8. Bilateral alveolar clefts (Superiorly based FAMM flap was done). 

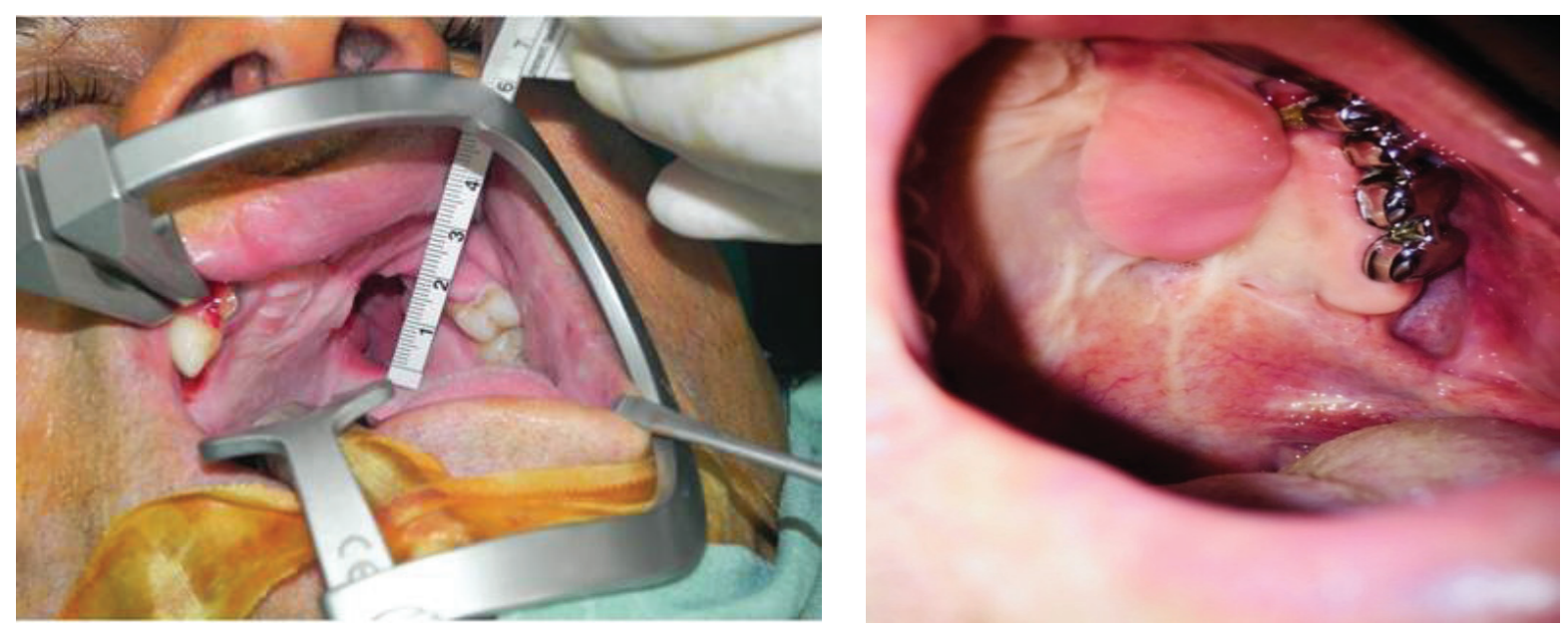

Fig. 9. A 40 years old man with palatal fistula and bone defect following a bullet injury. unilateral superiorly based FAMM flap done.

\section{DISCUSSION}

Palatal defects are difficult problems because they functionally affect the patients by nasal regurgitation and speech problems, apart from the anatomical defects. It most commonly occur as a complication of cleft palatal repair, resulting in a wide and scarred fistula. One of the most reasonable solutions for that is the use of a FAMM flap, composed of mucosa and submucosa with a part of the buccinators and orbicularis oris muscles along with the facial artery and vein. It can be designed according to the position and state of the defect either inferiorly or superiorly based (3). Being a kind of axial flap means the facial artery is included along the whole length of the flap which helps covering of a defect with the size of 3-8 cm without the risk of flap viability; in this way, it can be used for covering small to medium size palatal defects (1). The other benefit of the flap is the lack of risk of nerve injury as the facial artery is far deeper than the facial nerve branches, that is why the facial artery can be included safely in the flap through the whole length of the flap. There is also the advantage of replacing like with like as it uses oral mucosa for covering the mucosal defect. There is no external scar by using the FAMM flap as with nasolabial flap, so there will be a good aesthetic result. Furthermore, it can be used along with the tumor excision and reconstruction in the same operative field at the same operation time.

Our study shows the use of a FAMM flap for reconstruction of a palate defect. Due to the rich blood supply of the region, the flap could be raised safely. In all of our cases, primary closure was possible at the donor side. The flap is robust and thick, therefore gives enough bulk to the palate and allows the defect to be closed. Due to the leakage, using a prosthesis to closure of soft palatal defects mostly creates a poor functional outcome. Closure of large palatal defects have been usually accomplished with palatal prosthetic devices (12).

Other studies investigated the use of FAMM flap for reconstruction of palate defects. Doldere et al. (12) investigated the use of an extended FAMM flap with the appropriate mucosal muscle skin tissue for reconstruction of a soft palate defect. They concluded that this flap allows not only the treatment of the palatal defect, but also management of dribbling secondary to a marginal mandibular palsy.

Sumarroca et al. (1) investigated the reconstruction of oral cavity defects with 
FAMM flaps. In that study, reconstruction was successful in $92 \%$ of cases. Oral function and ingestion were satisfactory in all patients. Therefore, they concluded that the FAMM flap is useful and reliable for reconstruction of some small to medium-sized intraoral defects. The functional reconstruction of the oral cavity can be achieved with a low risk of complications (1). Xie et al. (13) studied modified FAMM flaps for reconstruction of posterior skull base defects. Using the fascia of the masseter muscle, they have developed a new modified FAMM flap. In addition, they concluded that the retrograde FAMM flap should only be applied as an alternative when other clinically proven options are not appropriate. Fang et al. (14) investigated various buccinator musculomucosal flaps for palatal fistulae closure after cleft palate surgery. They concluded that the flap is a suitable option for fistula repair. It is good for greater fistulae at the junction of hard and soft palate or at the anterior portion of the hard palate (14).

As a review of our cases, we believe that the FAMM flap is a very reliable and versatile flap used for palatal defect with a technically easy procedure with many advantages and minimal post-operative complications. We recommend its use for difficult small to medium sized palatal defects as a result of cleft palatal surgery complications or even any other causes of palatal defects.

\section{REFERENCES}

1. Sumarroca A, Rodriguez-Bauza E, Vega C, Fernandez M, Masià J, Quer M, León $\mathrm{X}$. Reconstruction of oral cavity defects with FAMM (facial artery musculomucosal) flaps. Our experience. Acta Otorrinolaringol Esp 2015;66:275-280.

2. Yehya AA, Gamaan I, Abd El Monem M, Fathy A. Outcomes of facial artery musculomucosal flap for closure of small and medium sized fistula after clefts. Egypt J Ear Nose Throat Allied Sci 2017;18(3):231-235.

3. Pribaz J, Stephens W, Crespo L, Gifford G. A new intraoral flap: facial artery musculo- mucosal (FAMM) flap. Plast Reconstr Surg 1992;90:421-429.

4. Brue E, Bey E, Cariou JL. Facial artery. Embryological review, descriptive and functional anatomy based on a review of the literature. Ann Chir Plast Esthet 2000;45:461-484.

5. Schulte DL, Sherris DA, Kasperbauer JL. The anatomical basis of the Abbe flap. Laryngoscope 2001;111:382-386.

6. Ayad T, Kolb F, De Mones E, Mamelle G, Temam S. Reconstruction of floor of mouth defects by the facial artery musculo-mucosal flap following cancer ablation. Head Neck-J SCI SPEC 2008;30:437-445.

7. Pribaz JJ, Meara JG, Wright S, Smith JD, Stephens W, Breuing KH. Lip and vermilion reconstruction with the facial artery musculomucosal flap. Plast Reconstr Surg 2000;105:864-872.

8. Anastassov GE, Schwartz S, Rodriguez E. Buccinator myomucosal island flap for postablative maxillofacial reconstructions: a report of 4 cases. J Oral Maxillofac Surg 2002;60:816-821.

9. Matros E, Swanson EW, Pribaz JJ. A modification of the facial artery musculomucosal flap for palatal reconstruction in patients with intact dentition. Plast Reconstr Surǵ 2010;125:645-647.

10. Hill C, Riaz M, Leonard AG. A technique for repair of the "unrepairable" cleft palate. Br J Plast Surg 1999;52:658-660.

11. Abou Chebel N, Beziat JL, Torossian JM. Reconstruction of the mouth floor using a musculo-mucosal buccinator flap supplied by facial vessels. Report of ten cases. Ann Chir Plast Esthet 1998;43:252-257.

12. Dolderer JH, Hussey AJ, Morrison WA. Extension of the facial artery musculomucosal flap to reconstruct a defect of the soft palate. J Plast Surg Hand Surg 2011;45:208-211.

13. Xie L, Lavigne P, Lavigne F, Ayad T. Modified facial artery musculomucosal flap for reconstruction of posterior skull base defects. J Neurol Surg Rep 2016;77(2):e98.

14. Fang $L$, Yang $M$, Wang $C$, Ma $T$, Zhao $Z$, Yin N, Wei L, Yin J. A clinical study of various buccinator musculomucosal flaps for palatal fistulae closure after cleft palate surgery. J Craniofac Surg 2014;25(2):e197202. 